\title{
Assessment of Hands on Skills in Operating Electrical Mixer Grinder in Rural and Remotes Villages
}

\author{
J. Kannan, D. Venkatrama Raju
}

\begin{abstract}
Rural consumer behavior refers to ultimate consumer buying behaviour. Individuals who buy products and services for personal or household use or consumption rather than for business purposes. The term rural consumer is defined as "the behavior that the rural consumers display in searching for purchasing, using, evaluating and disposing of products and services that they expect will satisfy their needs".
\end{abstract}

Keywords: Employee welfare, Globalization, Welfare

\section{INTRODUCTION}

The consumer and the customer are two difference terms. Customer is not always the consumer and the consumer is not always the customer. Customers, such as intermediaries, agents, etc. may or may not buy products for their own use, where they obtain the products for their own consumption as consumers. Consumer behavior is at stake here, and the consumer is an important factor[1]-[4].

\section{OBJECTIVES}

- The preference of the rural customer in consuming the butterfly mixer grinder.

- To identify the factors inducing the purchase of butterfly mixer grinder

- To ascertain the rural customer satisfaction towards butterfly mixer grinder.

- To offer some suggestion to improve the brand image of butterfly mixer grinder.

\section{RESEARCH METHODOLOGY}

The approach of the investigation incorporates the depiction of research structure, populace, test size, examining strategy improvement and portrayal of hardware information accumulation technique and strategy examination[5]-[9].

\section{A. RESEARCH DESIGN}

The scientists embrace to create data that is sufficient,

Revised Manuscript Received on December 11, 2019

J. Kannan, Department of Science and Humanities, Bharath Institute of Higher Education and Research, Chennai , India. Email: sjkannan1986@gmail.com

D. Venkatrama Raju, Department of Science and Humanities, Bharath prof.dvraju@gmail.com Institute of Higher Education and Research, Chennai, India. Email:

exact, objective and interpretable. Research configuration is blue print configuration study that amplifies the command over factor that could translate with the investigation want result.

\section{RESULTS AND DISCUSSION}

Majority $68 \%$ of the respondents are female.

It is discovered that $40 \%$ of the assenters are in the age bunch underneath 20 years.

It is discovered that larger piece of the assenters is under graduat level of $60 \%$.

It is discovered that larger part $65 \%$ of the assenters is unmarried.

Maximum $56 \%$ of the respondents are understudies.

Most $34 \%$ of the respondents month to month salary of Rs5000-Rs10000.

It is discovered that $40 \%$ of the respondents are utilizing butterfly blender processor for as far back as 3 years[10]-[14].

Maximum $75 \%$ of the respondents favored for nature of the item.

It is discovered that $36 \%$ of the respondents execution dependent on their own longing.

It is obvious from the their examination $32 \%$ of the respondents are acquiring in the general store.

$87 \%$ of the respondents are purchasing butterfly blender processor by prepared money.

Majority $74 \%$ of the respondents are utilizing this butterfly want model blender processor.

It is discovered that $47 \%$ of the respondents are utilizing 3 container blender processor model[15]-[18]

Most $39 \%$ of the respondents are utilizing red shading butterfly blender processor.

Maximum $95 \%$ of the respondents are happy with assurance of the organization.

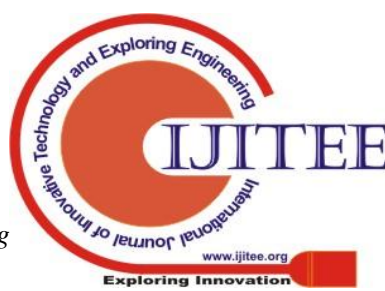




\section{Assessment of Hands on Skills in Operating Electrical Mixer Grinder in Rural and Remotes Villages}

Maximum $90 \%$ of the respondents are happy with warrantee of the organization.

Maximum $65.75 \%$ of the respondents' fantastic level in great.

The study infers $82 \%$ of the respondents feel upbeat, no client issue.

The Majority $68 \%$ of the respondents happy with administration focus.

Most $67 \%$ of the respondents uncovered that administration focus administration are great.

Most of the respondents $80 \%$ recommend not to change the leaving model

$40 \%$ of the respondents positioning brand name is the main position. $20 \%$ of the respondents give second position for style, shading. $27 \%$ of the respondents give third position for quality. $38 \%$ of the respondents give due position for cost.

It is inspected that, all in all Satisfaction score, the degree of hugeness was under 0.05 (5 percent level), and henceforth the invalid speculation was Rejected. It is seen that sexual orientation factor had affected the degree of fulfillment score of provincial clients towards Butterfly Mixer Grinder.

It is inspected that, all in all Satisfaction score, the degree of noteworthiness was under 0.05 (5 percent level), and subsequently the invalid speculation was Rejected . It is seen that age factor had impacted the degree of fulfillment score of rustic clients towards Butterfly Mixer Grinder.

It is inspected that, in general Satisfaction score, the degree of essentialness was more than 0.05 (5 percent level), and henceforth the invalid theory was Accepted. It is seen that instructive factor had not affected the degree of fulfillment score of country clients towards Butterfly Mixer Grinder.

It is inspected that, all in all Satisfaction score, the degree of criticalness was more than 0.05 (5 percent level), and thus the invalid speculation was Accepted. It is seen that conjugal status factor had not affected the degree of fulfillment score of rustic clients towards Butterfly Mixer Grinder.

It is inspected that, all in all Satisfaction score, the degree of importance was more than 0.05 (5 percent level), and henceforth the invalid speculation was Accepted. It is seen that word related factor had not impacted the degree of fulfillment score of country clients towards Butterfly Mixer Grinder.
It is inspected that, in general Satisfaction score, the degree of criticalness was more than 0.05 ( 5 percent level), and consequently the invalid speculation was Accepted. It is seen that salary factor had not affected the degree of fulfillment score of country clients towards Butterfly Mixer Grinder[19]-[21].

It is analyzed that, in general Satisfaction score, the degree of essentialness was more than 0.05 (5 percent level), and thus the invalid theory was Accepted. It is seen that utilization factor had not impacted the degree of fulfillment score of clients towards butterfly blender processor.

It is inspected that, in general Satisfaction score, the degree of centrality was more than 0.05 ( 5 percent level), and subsequently the invalid speculation was Accepted. It is seen that shading factor had not impacted the degree of fulfillment score of clients towards butterfly blender processor.

It is analyzed that, overall Satisfaction score, the degree of importance was under 0.05 (5 percent level), and subsequently the invalid speculation was dismissed. It is seen that certification factor had affected the degree of fulfillment score of clients towards butterfly blender processor.

It is analyzed that, overall Satisfaction score, the degree of noteworthiness was under 0.05 (5 percent level), and consequently the invalid theory was dismissed. It is seen that assurance factor had affected the degree of fulfillment score of clients towards butterfly blender grinder[22]-[24].

It is inspected that, all in all Satisfaction score, the degree of criticalness was more than 0.05 (5 percent level), and thus the invalid theory was Accepted. It is seen that purchasing affecting variable had not impacted the degree of fulfillment score of clients towards butterfly blender processor.

It is deduced that there is no basic association among age and most adored milk among the customers.

It is deduced that there is no basic association between wellsprings of acquisition and technique for portion.

It is contemplated that there is no immense association between wellsprings of acquisition and technique for portion.

\section{SUGGESTIONS}

- Additional facilities for usage may be offered to compete with each other brands.

- Prices may be fixed at a nominal rate so that people of all classes able to purchase.

- Give more advertisements in rural areas 
to get more market potential[25].

- The company must concentrate more to provide offers from time to time to improve the sales.

- The consumer expects more offers and discounts.

- The respondents suggested that more additional products should be introduced to the available products.

\section{CONCLUSION}

In conclusion it can be said that the behavior of rural consumer is not confined to a particular brand in case of mixer grinder. There is a common feeling that the prices charged by the retailers are more than the original price. Brand loyalty places an important are purchases of durable goods. There are many factors like advertisements, friends, family members, and price of products, sales promotional techniques, which influence the rural consumers to purchase a commodity or service.

\section{REFERENCES}

1) Vasanthi, S. \& Rabiyathul Basariya, S. 2019, "Influence of value analysis and cross training in industry", International Journal of Engineering and Advanced Technology, vol. 8, no. 6, pp. 1810-1811.

2) Velvizhi, R., Sri Gowtham, S. \& Jeya Priya, D. 2019, "Examination of early feedbacks for effective product retailing on E-commerce websites", International Journal of Engineering and Advanced Technology, vol. 8, no. 6 Special Issue 2, pp. 703-706.

3) Anuradha, C., Pothumani, S. \& Kavitha, R. 2019, "A novel method towards E-commerce", International Journal of Engineering and Advanced Technology, vol. 8, no. 6 Special Issue 2, pp. 535-538.

4) Thomas, J. \& Rabiyathul Basariya, S. 2019, "A study on the issues of financial ratio analysis", Indian Journal of Public Health Research and Development, vol. 10, no. 3, pp. 1079-1081.

5) Ramachandran, S. \& Rabiyathul Basariya, S. 2019, "Online marketing study on customer satisfaction and relationship", Indian Journal of Public Health Research and Development, vol. 10, no. 3, pp. 1072-1078.

6) Priya, R., Vinothini, G. \& Cor Jesu, C.D. 2019, "The mentor-protégé relationship for professional growth", Journal of Advanced Research in Dynamical and Control Systems, vol. 11, no. 9 Special Issue, pp. 1110-1119.

7) Jannifer Rani, N., Bina Pani, S. \& Nimisha, N.S. 2019, "A study on money back polices available in LIC", Journal of Advanced Research in Dynamical and Control Systems, vol. 11, no. 9 Special Issue, pp. 833-839.

8) Saillaja, V., Jhansi Rani, K. \& Catherine, R. 2019, "Global marketing management planning and organization", Journal of Advanced Research in Dynamical and Control Systems, vol. 11, no. 9 Special Issue, pp. 489-493.

9) Saillaja, V., Jhansi Rani, K. \& Catherine, R. 2019, "The new phase of marketing information system", Journal of Advanced Research in Dynamical and Control Systems, vol. 11, no. 9 Special Issue, pp. 482-488.

10) Thoufiqulla \& Raju, D.V. 2019, "Perception of indian investor towards investment in mutual funds with special reference to mip funds", Journal of Advanced Research in Dynamical and Control Systems, vol. 11, no. 5, pp. 177-183.

11) Jasmine, K.R.M. \& Basariya, S.R. 2018, "A study on the customers benefits on mutual funds", International Journal of Civil Engineering and Technology, vol. 9, no. 4, pp. 45-48.

12) Vasanthi, S. \& Basariya, S.R. 2019, "Pros and cons of on the job training versus off the job training", International Journal of Scientific and Technology Research, vol. 8, no. 10, pp. 671-674.

13) Pavithra, J. \& Ganesan, M. 2016, "A study on awareness and impact of micro-financial schemes", International Journal of Applied Business and Economic Research, vol. 14, no. 8, pp. 5449-5460.

14) Pavithra, J., Dilli Babu, P. \& Ambuli, T.V. 2014, "A study on budgetary control at Maruti Service Masters, Chennai", International Journal of Applied Business and Economic Research, vol. 12, no. 2, pp. 151-161.

15) Gunaraja, T.M. \& Venkatrama Raju, D. 2018, "Determining factors of organisational climate with reference to leadership styles", International Journal of Mechanical Engineering and Technology, vol. 9, no. 9, pp. 1327-1332.
16) Gunaraja, T.M. \& Venkatrama Raju, D. 2018, "The role of job satisfaction and training of employees in determining organisational climate of a selected industry", International Journal of Civil Engineering and Technology, vol. 9, no. 8, pp. 1266-1269.

17) Aarathy, T.S. \& Raju, D.V. 2018, "Performance appraisal and its effects on employees with respect to it sector in Chennai city", International Journal of Civil Engineering and Technology, vol. 9, no. 6, pp. 1535-1538.

18) Aarathy, T.S. \& Raju, D.V. 2018, "Employee perception towards performance appraisal system in IT sector", International Journal of Mechanical Engineering and Technology, vol. 9, no. 5, pp. 131-135.

19) Porselvi, W., Jublee, D. \& Sivanesan, G. 2018, "A study on factors influencing adoption of technology and innovation in banking industry, tamilnadu, India", International Journal of Mechanical Engineering and Technology, vol. 9, no. 5, pp. 789-800.

20) Akessa, G.M. and Dhufera, A.G., 2015. Factors That Influences Students Academic Performance: A Case of Rift Valley University, Jimma, Ethiopia. Journal of Education and Practice, 6(22), pp.55-63.

21) Miller, G. and Shih, C.C., 1999. A faculty assessment of the academic rigor of on-and off-campus courses in agriculture. Journal of Agricultural Education, 40, pp.57-65.

22) Tsinidou, M., Gerogiannis, V. and Fitsilis, P., 2010. Evaluation of the factors that determine quality in higher education: an empirical study. Quality Assurance in education, 18(3), pp.227-244.

23) Farooq, M.S., Chaudhry, A.H., Shafiq, M. and Berhanu, G., 2011. Factors affecting students' quality of academic performance: a case of secondary school level. Journal of quality and technology management, 7(2), pp.1-14

24) Fitsilis, P., Gerogiannis, V. and Anthopoulos, L., 2014. Ontologies for software project management: a review. Journal of Software Engineering and Applications, 7(13), p.1096.

25) Adams, J.D. and Jaffe, A.B., 1996. Bounding the effects of R\&D: an investigation using matched establishment-firm data(No. w5544). National bureau of economic research.

\section{AUTHORS PROFILE}

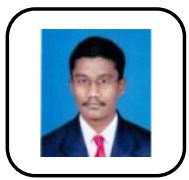

J. Kannan Associate Professor, Department of Science and Humanities, Bharath Institute of Higher Education and Research, Chennai, India.

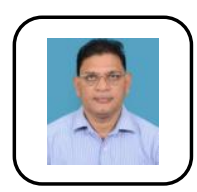

D. Venkatrama Raju Professor, Department of Science and Humanities, Bharath Institute of Higher Education and Research, Chennai, India. 